УДК 342.951

DOI https://doi.org/10.32837/pyuv.v0i1(30).535

\author{
О. М. Шевчук \\ orcid.org/0000-0003-4864-7316 \\ доктор юридичних наук, \\ професор кафедри адліністративного права \\ та адміністративної діяльності \\ Національного юридичного університету імені Ярослава Мудрого \\ Д.С. Юхименко \\ orcid.org/0000-0002-2031-2971 \\ студентка II курсу міжнародно-правового факультету \\ Національного юридичного університету імені Ярослава Мудрого
}

\title{
НАДАННЯ ЗГОДИ ПРИ ТРАНСПЛАНТАЦІЇ АНАТОМІЧНИХ МАТЕРІАЛІВ ЛЮДИНИ В УКРАЇНІ ТА ЄС: ПОРІВНЯЛЬНО-ПРАВОВИЙ АНАЛІЗ
}

Постановка проблеми. У сучасних умовах реформування системи охорони здоров'я України актуальною є проблема «надання згоди» при трансплантації анатомічних матеріалів людини. Актуальним це питання $е$ і для більшості країн. У всьому світі є проблема дефіциту органів для пересадки, однак його співвідношення 3 чисельністю населення значно відрізняється залежно від правової та соціальної конструкції донорських систем [1, с. 12]. В Україні за 2018 р. було зроблено загалом 126 трансплантацій, за кордоном 121 пацієнта прооперовано [2]. У 2020 р. КМ України затвердив тарифи на послуги з трансплантації органів та інших анатомічних матеріалів. Наприклад, алотрансплантація нирки (від живого донора або донора-трупа) вартістю у 323798 грн, АВО-несумісна алотрансплантація нирки у 72123 грн, пересадка печінки/частини печінки - реципієнту 855039 грн [3], що є набагато нижчою, ніж в інших країнах. У 2020 р. з бюджету України оплачено близько 100 трансплантацій, а також заплановано на 2020 р. 112 млн грн на всі види трансплантацій. На методи трансплантації наших громадян в зарубіжних країнах заплановано витратити з бюджету 1,1 млрд грн [4]. При ефективній системі правового регулювання трансплантації в Україні ці кошти можна було використати в національній системі охорони здоров'я. В юридичній науці й досі не знайдено єдиного підходу переваг та недоліків у процесі застосування таких категорій, як «надання згоди або незгоди» при посмертному донорстві. Крім того, прогалини як у теорії, так і в законодавстві із вказаної проблематики, впливають на виконання практичних завдань, що і вказує на актуальність дослідження і практичне його значення.

Аналіз останніх досліджень та публікацій. Дослідженням питання «надання згоди» при посмертному донорстві займалася низка науковців таких, як В.М. Пашков, який проаналізував правові аспекти презумпції згоди при трансплантації анатомічних матеріалів померлої людини [5]. Г.В. Анікіна вивчила такі питання, як право людини на збереження свого тіла після смерті, визначила коло родичів та їхні права щодо розпорядження тілом померлого [6], Я.О. Брюховецька звернула увагу на проблемні питання надання погодження або непогодження на донорство органів після смерті особи [7], Г.Р. Галеєва детально розглянула види статусу реципієнтів та посмертних донорів на різних етапах трансплантації [8], Я.О. Ковальова та Г.А. Білецька зосередили увагу на взаємозв'язку медичних, етичних та правових проблем трансплантації [9], I.M. Танасійчук запропонував ввести до чинного законодавства зміни щодо позбавлення родичів права надавати згоду на взяття трансплантатів від померлого донора [10] та ін. Водночас окремі питання аналізу порівняльно-правових аспектів надання згоди в процесі трансплантації анатомічних матеріалів людини в сучасних умовах залишилися поза увагою науковців та $є$ актуальним завданням у науці адміністративного права.

Постановка завдання. Метою статті є аналіз особливостей адміністративно-правового регулювання «надання згоди» при посмертному донорстві в Україні та окремих країнах $Є C$, а також виявлення напрямів удосконалення національного законодавства з урахуванням їх позитивного досвіду.

Виклад основного матеріалу дослідження. Трансплантація органів людини має враховувати: а) інтереси реципієнтів, тобто осіб, які потребують медичної допомоги із застосуванням трансплантації, адже таких людей велика кількість і досить часто просто неможливо врятувати їхнє життя без проведення такої процедури; б) дотримання прав живих донорів та членів сім'ї тих осіб, що надають згоду на посмертне донорство; в) врахування етичних, духовних та релігійних цінностей суспільства та ін. [11, с. 17]. 
Згідно $з$ положеннями Закону України «Про застосування трансплантації анатомічних матеріалів людині» термін «трансплантація» визначено як спеціальний метод лікування, що полягає в пересадці анатомічного матеріалу людини від донора реципієнту і спрямований на відновлення здоров'я людини (ст. 1) [12]. У розділі IV даного Закону вказано, що кожна повнолітня дієздатна особа має право подавати письмову згоду або незгоду на посмертне донорство, або ж змінювати своє рішення шляхом відкликання своєї письмової згоди або незгоди на посмертне донорство та укладення нової заяви. Такі заяви особи, яка висловлює своє волевиявлення, мають бути засвідчені її підписом (ч. 2,4 ст. 16) [12]. Відомості, які вносяться до Єдиної державної інформаційної системи трансплантації органів та тканин, передбачені ч. 5 ст. 16 цього ж Закону [12]. За бажанням особи можуть вноситися відмітки про такі відомості до паспорта громадянина України та/або посвідчення водія України на право керування транспортними засобами (ч. 5 ст. 16) [12].

Кожна повнолітня дієздатна особа має право призначити свого повноважного представника, який надасть згоду на вилучення органів та/або тканин після її смерті (ч. 7 ст. 16), і ця інформація також вноситься до Єдиної державної інформаційної системи. У разі відсутності представника трансплантат-координатор запитуе про згоду на таке вилучення особисто в другого з подружжя або в одного з близьких родичів цієї особи (діти, батьки, рідні брати та сестри), або ж за відсутності таких в особи, яка зобов'язується поховати померлу особу (ч. 11 ст. 16) [12]. Дозволяється вилучення матеріалів для трансплантації в донора-трупа після підписання акта констатації смерті його головного мозку (ч. 1 ст. 17) [12]. Заборонено вилучення анатомічних матеріалів у померлої людини: 1) за наявності в Єдиній державній інформаційній системі трансплантації органів та тканин інформації про надану такою особою прижиттєво письмову незгоду на посмертне донорство, а також за відсутності письмової згоди: а) її повноважного представника; б) другого з подружжя або одного з близьких родичів; в) письмової згоди особи, яка зобов'язалася поховати померлого, батьків особи віком до 18 років або інших її законних представників; 2) у разі отримання заборони на вилучення анатомічних матеріалів із тіла донора-трупа закладом охорони здоров'я відповідно до рішення суду або правоохоронних органів; 3) за наявності обгрунтованих заперечень судово-медичного експерта або судового рішення або рішення органу досудового розслідування про проведення судової експертизи (ч. 3 ст. 17) [12]. Також є визначений перелік осіб, в яких також забороняється проведення таких маніпуляцій, а саме: а) у дітей-сиріт та дітей, позбавлених батьківського піклування; б) осіб, визнаних недієздатними; в) осіб, особистість яких не встановлена; г) осіб, які загинули в результаті проведення АТО та інших бойових дій та інші випадки (ч. 4 ст. 17) [12]. Отже, на законодавчому рівні впроваджені такі положення, як функціонування Єдиної державної інформаційної системи трансплантації органів та тканин, врегульовані випадки, коли заборонено вилучення анатомічних матеріалів у померлої людини i дозволено. 3 огляду на зміст Закону України «Про застосування трансплантації анатомічних матеріалів людині» діє «презумпція незгоди». Вона передбачає прижиттєве розпорядження донора чи згоду членів його сім’ї після його смерті. Зауважимо, що така правова конструкція забору органів, крім України, застосовується в інших країнах (США, Великобританії, Нідерландах, Німеччині, Японії) [5, с. 127]. У Британії, наприклад, надати таку згоду можна під час оформлення водійських прав [7, с. 93]. Презумпція згоди - це коли людина за життя не повідомляла, що вона проти трансплантації своїх органів, тому вважається, що після смерті iї органи можуть бути використані як донорські і при цьому не потрібно отримувати згоду родичів померлого. Такий принцип використовується у таких країнах, як Іспанія, Фінляндія, Португалія, Австрія, Греція, Франція, Бельгія [5, с. 128].

В юридичних колах $є$ прихильники як застосування принципу «надання згоди», так $\mathrm{i}$ «надання незгоди» в процесі визначення питання посмертного донорства. Так, С.Г. Стеценко стверджує, що концепція надання незгоди $є$ більш доречною в застосуванні, адже вона дає змогу ефективніше захищати права та інтереси громадян при отриманні медичної допомоги, а також забезпечити законність вираження волі посмертного донора [13, с. 46]. В.М. Пашков вказує, що застосування «презумпції згоди» в трансплантації суперечить п. 5 Декларації стосовно трансплантації людських органів, прийнятої Всесвітньою медичною асамблеєю у 1987 р. [5, с. 127]. Натомість М.Н. Комашко вважає, що, навпаки, принцип «надання згоди» дає змогу не лише розширити сферу застосування трансплантації та забезпечити збільшення кількості донорських матеріалів, але його впровадження призведе до посилення міжнародного співробітництва з іншими країнами світу [14, с. 18]. М.С. Брюховецька також поділяє цю позицію і зазначає, що цей принцип веде до швидкого лікування хворих [7, с. 93]. Отже, ми підтримуємо думку С.Г. Стеценка та В.М. Пашкова щодо концепції «надання незгоди» на трансплантацію анатомічних матеріалів людини за життя, бо витримуються повага та гідне ставлення до тіла померлого і забезпечується дотримання конституційних прав і свобод.

Розглянемо законодавчі аспекти надання незгоди в процесі трансплантації органів у Німеччині. Так, згідно з положеннями Федерального 
Закону Німеччини «Про пожертвування, пошук і передачу органів і тканин» від 05.11.1997 р. за назвою «Вилучення за згодою донора» встановлено, що вилучення органів та тканин дозволяється тільки, якщо: 1) є згода донора на таке вилучення; 2) смерть органів або тканин донора встановлена відповідно до прийнятих правил; 3) процедура виконується лікарем (п. 1 § 3) [15]. Якщо ж потенційний донор не надав ані письмової згоди при житті, ані заперечень на вилучення своїх органів після смерті, то лікарі, що констатують смерть особи звертаються до близьких родичів померлого для встановлення факту інформованості про волю їхнього родича (п. 1 § 4) [15]. Таким чином, згідно із законодавством ФРН, за життя мала бути письмова згода особи бути донором, що вноситься до так званого «заповіту пацієнта» (Patientenverf gung) [16] або ж до «карти донора органів» (Spenderausweis) [17]. Якщо ж таких відомостей немає, то право на надання згоди або незгоди делегується рідним вже померлої особи.

$\mathrm{y}$ державах, які на законодавчому рівні закріпили презумпцію згоди, окреслюється, що вилучення органів та тканин померлого для трансплантації дозволяється, якщо померла особа за життя не висловила заперечень на пересадку органа іншій людині в разі своєї смерті і ця згода мала бути зафіксована в офіційних документах або реєстрах, як і у випадку з презумпцією незгоди [18, с. 27]. Всесвітня асамблея охорони здоров'я 21 травня 2010 р. прийняла резолюцію WHA63.22 «Трансплантація органів та тканин людини», яка підтверджує оновлений її варіант, відповідно до якої для проведення трансплантації клітини, тканини та органи можуть бути вилучені з тіл померлих, якщо отримано згоду на це у формі, визначеній законом, і немає підстав вважати, що померла особа заперечувала проти такого вилучення (принцип 1) [19].

Яскравим прикладом країни, де на законодавчому рівні закріплено презумпцію надання згоди, є Франція. У цій країні за статистикою $92 \%$ органів або тканин надходять від померлої людини. Дозвіл на вилучення органів або тканин померлої людини має назву «акт щедрості і солідарності» (un acte de g n rosit et de solidarit ) [20]. У зв'язку з прийняттям 22 грудня 1976 р. закону Кайлавета (loi Caillavet) вперше було закріплено принципи, на яких грунтується посмертне донорство у Франції й нині: 1) надання згоди: будь-яка людина може стати донором органу, якщо вона не заявила про свою відмову впродовж життя; 2) безплатність: будь-яка винагорода або еквівалентна перевага в обмін на донорство органів є забороненою; 3) принцип анонімності, під яким розуміється, що ім'я донора не може бути повідомлено реципієнту і навпаки. Сім'я донора, проте, може бути поінформована про вилучення органів або тканини, а також про результат проведеної трансплантації, якщо вони запитають про це медичних працівників [21]. Якщо ж в Україні, згідно зі ст. 1 ЗУ «Про застосування трансплантації анатомічних матеріалів людині», встановлено Єдину державну інформаційну систему трансплантації органів та тканин [12], то у Франції діє система під назвою «Національний реєстр відмов», що підтверджується законом про модернізацію системи охорони здоров'я від 26 січня 2016 р. [22], який забезпечує онлайн-доступ до національного реєстру відмов, керівником якого є Агентство з біомедицини. Саме цей орган, згідно зі ст. L1232-1 Кодексу Франції про охорону здоров'я, є уповноваженим організовувати належне функціонування системи трансплантацій [23]. Згідно з положеннями цього закону дані до реєстру вносяться в онлайн-режимі й для цього треба лише відсканувати або сфотографувати документ, що засвідчує особу (посвідчення особи, паспорт, водійські права, посвідка на проживання [23]. Вважаємо, що це $є$ позитивним досвідом для України і пропонуємо запровадити такі зміни в питанні доступу до реєстру в онлайн-режимі, що значно спростить отримання такої інформації шляхом використання відсканованого або сфотографованого документа, що посвідчує особу. Зокрема, за Законом України від 17.05.2018 р. № 2427-VIII, а саме за ч. 5 ст. 16 , документами, до яких можуть вносити відмітки про надання згоди/незгоди, є паспорт та водійські права [12]. Як зазначено в законі Кайлавета від 1976 р. особа має змогу виразити не лише тотальну незгоду на проведення такої маніпуляції після смерті, але й заперечити тільки проти донорства окремих органів або тканин [21].

Згідно зі ст. L 1231-1 Кодексу про охорону здоров'я Франції та Законом від 26 січня 2016 р. «про модернізацію системи охорони здоров'я" визначено такі способи вираження відмови: 1) надання близькій людині письмової та підписаної заяви, а родич має надати такого листа медичним працівникам після смерті особи; 2) якщо ж особа бажає висловити свою волю письмово, але не може самостійно написати заяву через хворобу, такий документ може бути складений третьою особою в присутності двох свідків; 3) відмова особи може бути виражена в усній формі, що дає змогу довести свою відмову до родичів, які передадуть останню волю особи в усній формі на момент смерті особи. $\mathrm{y}$ цьому випадку родичі особи мають повідомити лікарів про обставини, за яких була виражена відмова, та підписати стенограму, яка буде складена в письмовому вигляді $[24 ; 22]$.

Іншим прикладом слугує Бельгія, де також діє концепція «надання згоди». Доцільно вказати, що до законодавчої бази врегулювання посмертного донорства варто зарахувати Закон від 13.06.1986 p. «Про вилучення та трансплантацію 
органів». Згідно з положеннями цього Закону дозволяється посмертне вилучення органів кожного громадянина Бельгії, який має постійне місце проживання в Бельгії (ст. $10 \S 1$ ) [25]. Корисним для України може бути те, що вказані норми Закону розкривають основну особливість правового регулювання посмертного донорства шляхом обмеження такими критеріями: 1) наявність громадянства; 2) постійне місце проживання потенційного донора на території держави.

Висновки. На підставі вищезазначеного вважаємо, що апробації інституту трансплантації в окремих країнах (Франція, Бельгія) можуть бути покладені для удосконалення законодавства з питань трансплантації органів при посмертному донорстві в Україні. Запропоновано внести до Закону України «Про застосування трансплантації анатомічних матеріалів людині» зміни: 1) забезпечити доступ до єдиної державної інформаційної системи в онлайн-режимі шляхом використання відсканованого чи сфотографованого документа, що посвідчує особу; 2) закріпити можливість письмового вираження не лише тотальної незгоди трансплантації після смерті, але й заперечити тільки проти донорства окремих органів або тканин; 3) врегулювати процедуру вираження волі особи щодо надання згоди/незгоди через хворобу та надання можливості складення такої письмової заяви третіми особами в присутності кількох свідків, що сприятиме забезпеченню законності цієї процедури.

\section{Jimepamypa}

1. Караева О. Донорство органов: проблемы и перспективы развития в России. Аналитический Центр Юрия Левады. Москва, 2013. 72 с.

2. Проведено першу трансплантацію нирки у районній лікарні України. Офіційний сайт МОЗ України. URL: https://moz.gov.ua/article/news/provedenopershu-transplantaciju-nirki-u-rajonnij-likarni-ukraini (дата звернення: 17.04.2020).

3. МОЗ України оплатив трансплантації на 2020 рік. URL: https://interfax.com.ua/news/pharmacy/633655. htmlhttps://moz.gov.ua/article/news/provedenopershu-transplantaciju-nirki-u-rajonnij-likarni-ukraini (дата звернення: 17.04.2020).

4. В Україні лікують мертвих і не рятують живих. Нові правила пересадки органів: що тепер зміниться. URL: https://glavcom.ua/country/health/v-ukrajinilikuyut-mertvih-i-ne-ryatuyut-zhivih-zastupnikministra-ohoroni-zdorovya-pro-novi-pravila-peresadkiorganiv-656221.html (дата звернення: 17.04.2020).

5. Пашков B.M. Анатомічні матеріали померлої людини: презумпція згоди. Український мед. часопис. 2013. 6 (98) - XI/XII. C. 126-128.

6. Анікіна Г.В. Особливості правового регулювання трансплантації органів від померлого донора. Юридична Україна. 2010. № 10. С. 68-75.

7. Брюховецька М.С. Посмертне донорство органів: презумпція погодження або непогодження. Науковий вісник Ужгородського національного університету. 2016. Квітень. С. 91-94.

8. Галеева Г.Р. Некоторые аспекты предлагаемых изменений законодательства в области транспланта- ции органов в России. Проект Федерального Закона «О донорстве органов человека и их трансплантации». Вестник Волжского университета илени В.Н. Татищева. № 4(81). 2014. С. 4-10.

9. Білецька Г.А., Ковальова Я.О. Трансплантологія в Україні: медичні та юридичні аспекти проблеми. Медичне право. 2013. № 3. С. 103-110.

10. Танасійчук О.М. Посмертне донорство в Україні та Російській Федерації: порівняльно-правовий аналіз. Правова держава. 2016. № 23. С. 120-124.

11. Малярчук В.И., Степанова Е.Н., Степанов Н.В. 0 «презумпции согласия» в правовом регулировании трансплантации органов человека. Вестник РУДН: серия Медииина. 2002. № 3. С. 17-21.

12. Про застосування трансплантації анатомічних матеріалів людині : Закон України від 17.05.2018 p. № 2427-VIII. URL: https://zakon.rada.gov.ua/laws/ show/2427-19 (дата звернення: 17.04.2020).

13. Стеценко С.Г. Трансплатология: юридические проблемы. Законность. 2004. № 11. С. 44-46.

14. Комашко М.Н. Проблема презумпции согласия на изъятие органов и (или) тканей для трансплантации. Медииинское право. 2006. № 3 (15). С. 16-22.

15. Gesetz über dieSpende, Entnahme und Übertragung von Organen und Geweben (Transplantationsgesetz TPG). URL: https://www.gesetze-im-internet.de/tpg/ TPG.pdf (Last accessed: 17.04.2020).

16

Patientenverfügung.

URL: https://www.bundesgesundheitsministerium.de/ patienten-verfuegung.html (Last accessed: 17.04.2020).

17. Füllen Sie den Organspendeausweis online aus oder bestellen Sie ihn kostenfrei. URL: https://www.organspende-info.de/organspendeausweisdownload-und-bestellen.html (Last accessed: 17.04.2020).

18. Козлова А.А. Роль международно-правовых норм в формировании законодательства, регулирующего вопросы трансплантации и донорства в России и за рубежом. Международно-правовые исследования. Юристь-правовед. 2017. № 1. С. 25-29.

19. Керівні принципи ВООЗ з трансплантації клітин, тканин та органів людини від 2010 року. URL: https://www.who.int/transplantation/Guiding PrinciplesTransplantation_WHA63.22ru.pdf (дата звернення: 17.04.2020).

20. Les modalités du don d'organes ou de tissus. Ministère des Solidarités et de la Santé. URL: https://solidarites-sante.gouv.fr/systeme-de-sante-etmedico-social/parcours-de-sante-vos-droits/respect-dela-personne-et-vie-privee/article/les-modalites-du-dond-organes-ou-de-tissus (Last accessed: 17.04.2020).

21. Loi n 76-1181 du 22 décembre 1976 relative aux prélèvements d'organes. URL: https://www.legifrance.gouv.fr/affichTexte.do? cidTexte=JORFTEXT00000069940 (Last accessed: 17.04.2020).

22. LOI $\mathrm{n}^{\circ}$ 2016-41 du 26 janvier $2016 \mathrm{de}$ modernisation de notre système de santé. URL: https://www.legifrance.gouv.fr/affichTexte.do; jsessionid=FAA49E653FA9E7911807FE279900EFCC. tplgfr23s 3?cidTexte=JORFTEXT000031912641\& dateTexte $=29990101$ (Last accessed: 17.04.2020).

23. Code de la santé publique - Article L1232-1. URL: https://www.legifrance.gouv.fr/affichCodeArticle.do?idArticle $=$ LEGIARTI000031931933\&cidTexte $=$ LEGITEXT000006072665\&dateTexte $=20170101$ (Last accessed: 17.04.2020).

24. Code de la santé publique - Article L1231-1. URL: https://www.legifrance.gouv.fr/affichCodeArticle.do?idArticle $=$ LEGIARTI000006686147\&cidTexte $=$ LEGITEXT000006072665\&dateTexte $=20040807$. (Last accessed: 17.04.2020). 
25. Wet van 13 juni 1986 betreffende het wegnemen en transplanteren van organen. URL: https://www. ejustice.just.fgov.be/cgi loi/change lg.pl?language $=\mathrm{n}$ $1 \& \mathrm{la}=\mathrm{N} \& \mathrm{cn}=1986061337 \&$ table name $=$ wet (Last accessed: 17.04.2020).

\section{Анотація}

Шевчук О. М., Юхименко Д. С. Надання згоди при трансплантації анатомічних матеріалів людини в Україні та ЄС: порівняльно-правовий аналіз. - Стаття.

У статті з'ясовано особливості адміністративно-правового регулювання надання презумпції згоди при трансплантації анатомічних матеріалів людини в Україні та окремих країнах Свропейського Союзу. 3'ясовано, що трансплантація - це спеціальний метод лікування, що полягає в пересадці анатомічного матеріалу людини від донора реципієнту та спрямований на відновлення здоров'я людини. Розкрито, що в Законі України «Про застосування трансплантації анатомічних матеріалів людині» застосовується презумпція «незгоди», яка передбачає прижиттєве розпорядження донора чи згоду членів його сім'ї після його смерті. Презумпція «незгоди» стосовно трансплантації органів застосовується в США, Великобританії, Нідерландах, Німеччині, Японії. Встановлено, що презумпція згоди на трансплантації органів - це коли людина за життя не повідомляла, що вона проти трансплантації своїх органів, тому вважається, що після смерті її органи можуть бути використані як донорські і при цьому не треба отримувати згоду родичів померлого. Використовується в таких країнах: Іспанія, Фінляндія, Португалія, Австрія, Греція, Франція, Бельгія.

Визначено сутність функціонування Єдиної державної інформаційної системи трансплантації органів та тканин, вказано випадки заборони та дозволу вилучення анатомічних матеріалів у померлої людини. Проаналізовано, що в наукових колах є прихильники як застосування презумпції згоди, так і презумпції незгоди щодо визначення питання посмертного донорства. Автор підтримує наукову концепцію презумпціі незгоди, взявши за основу те, що при цьому поважають та гідно ставляться до тіла померлого і забезпечується дотримання конституційних прав і свобод.

Аргументовано доцільність внесення змін до Закону України «Про застосування трансплантації анатомічних матеріалів людині" щодо надання презумпції згоди /незгоди: 1) забезпечити доступ в онлайн-режимі шляхом використання відсканованого чи сфотографованого документа, що посвідчує особу; 2) закріпити можливість письмового вираження 3 питань донорства окремих органів або тканин; 3) врегулювати процедуру вираження волі особи щодо надання згоди/незгоди через хворобу та надання можливості складення такої письмової заяви третіми особами у присутності кількох свідків, що сприятиме забезпеченню законності цієї процедури.

Ключові слова: адміністративно-правове регулювання, посмертне донорство, надання згоди, тран- сплантація анатомічних матеріалів людини, надання незгоди, донор, реципієнт.

\section{Summary}

Shevchuk O. M., Yukhymenko D. S. Giving consent for transplantation of human anatomical material in Ukraine and the EU: A comparative legal analysis. - Article.

The article looks into the particularities of the administrative and legal regulation of giving the presumed consent in connection with transplantation of human anatomical material in Ukraine and certain countries of the European Union. Transplantation has been found to be a special treatment method involving transfer of human anatomical material from the donor to the recipient and aimed at restoring human health. It is found out that the Law of Ukraine "On the Application of Transplantation of Human Anatomical Material" uses the presumed "refusal» that provides for the donor's lifetime order or the consent of his family members after his death. The presumed "refusal" in respect of organ transplantation is used in the USA, United Kingdom, Netherlands, Germany, Japan. It has been established that the presumed consent to organ transplantation means that a person did not declare during the lifetime that she was set against transplantation of her organs, so it is believed that after her death, her organs can be used as donor's ones and it is not required to obtain consent from the deceased's relatives. It is used in Spain, Finland, Portugal, Austria, Greece, France, Belgium.

The operation of the Unified State Information System for Transplantation of Organs and Tissues is made clear and the cases where it is prohibited or allowed to collect the deceased's anatomical material are given. The analysis findings show that in the scholarly works, there are both supporters of use of the presumed consent and supporters of use of the presumed refusal when dealing with the issue of cadaveric donation. The scientific concept of presumed refusal is supported, taking as its basis the respect for and bona fide attitude to the body of the deceased and the ensuring of observance of the constitutional rights and freedoms.

The reasonableness of amending the Law of Ukraine "On the Application of Transplantation of Human Anatomical Material" in terms of giving the presumed consent/refusal is set forth forcefully, in particular, it is necessary: 1) to provide online access through the use of a scanned or photographed identity document; 2 ) to entrench the opportunity of expressing in writing the position on the issues of donation of certain organs or tissues; 3 ) to provide, in connection with a disease, for the making of a written declaration by third parties in the presence of a number of witnesses for transplantation of organs, as such declaration will facilitate the ensuring of the lawfulness of this procedure.

Key words: administrative and legal regulation, cadaveric donation, giving consent, transplantation of human anatomical material, giving refusal, donor, recipient. 